\title{
Harga diri (self esteem) lansia yang mengalami demensia
}

\author{
Ganda Sigalingging ${ }^{1 *}$, Zulkarnain Nasution ${ }^{2}$, Rustina Pasaribu ${ }^{3}$ \\ 1,2,3 Fakultas IImu Keperawatan Universitas Darma Agung Medan. *Email: gandabonagabe@gmail.com
}

\section{Abstract \\ Self esteem in elderly persons with dementia}

Background : The triple threat is a challenge that must be faced in Indonesia. More and more the number of elderly that continues to increase. As you age, changes occur due to the aging process that causes physical and psychosocial problems. one of the psychosocial problems in the elderly is low self-esteem. If that doesn't work, the elderly will repair, attract, challenge, and even escape.

Purpose :To analyze the relationship between dementia and self-esteem (self-esteem) in the elderly at the Guna Budi Bakti Foundation in Medan.

Method: This analytical survey research cross sectional approach. Seventy two elderlywere involved as the population in this research.This research used total sampling technique where in the number of sample equals to the number of population. In analyzing the data, chi-square test was used.

Results: Shows that older people reduce moderate dementia $44.4 \%$ with a low self-esteem $69.4 \%$. With the statistical test results there was a relationship dementia and self-esteem in the elderly, with p-value of 0.003 Conclusion: There was a relationship dementia with of self-esteem for elderly in Panti Jompo Guna Budi Bakti Foundation in Medan

\section{Keywords: Dementia; Self-esteem; Elderly}

Pendahuluan: Ancaman triple burden merupakan tantangan yang harus dihadapi di Indonesia. Ancaman tersebut diantaranya jumlah lansia yang terus meningkat. Seiring pertambahan usia, terjadi perubahan sebagai akibat proses menua yang berpotensi menimbulkan masalah fisik dan psikososial. Salah satu masalah psikososial pada lansia yaitu harga diri rendah. jika tidak ditangani maka lansia mengalami depresi, menarik diri, perilaku kekerasan bahkan bunuh diri.

Tujuan : Untuk menganalisa hubungan demensia dengan harga diri (self esteem) lansia di Yayasan Guna Budi Bakti Medan.

Metode: Jenis penelitian survei analitik dengan pendekatan cross sectional. Populasi seluruh lansia sebanyak 72 orang dengan teknik sampel total sampling. Pengumpulan data dilakukan dengan wawancara menggunakan kuesioner. Analsisi data menggunakan uji chi- Sguare pada taraf kepercayaan $95 \%$.

Hasil: Menunjukkan lansia lebih banyak mengalami demensia sedang, sebanyak 32 orang (44,4\%). dengan menunjukkan harga diri rendah sebanyak 50 orang $(69,4 \%)$. Hasil uji statistik menunjukkan ada hubungan demensia dengan harga diri (self estem) lansia, dengan nilai $p$ value $=0,003(a<0,05)$

Simpulan: Ada hubungan demensia dengan harga diri (self esteem) lansia di Panti Jompo Yayasan Guna Budi Bakti Medan.

\section{Kata Kunci : Demensia; Harga diri; Lansia}

\section{PENDAHULUAN}

Seiring dengan semakin meningkatnya populasi lanjut usia akan membawa dampak di berbagai aspek kehidupan lansia. Salah satu aspek terpenting adalah masalah kesehatan, bukan saja hanya penyakit kronis atau penyakit degeneratif, melainkan juga kerentanan terhadap infeksi.Salah satu masalah kesehatan yang paling umum terjadi pada kelompok lansia adalah demensia. Demensia merupakan kemunduran kognitif yang sedemikian beratnya, sehingga mengganggu aktivitas sosial dan pekerjaannya. Pada demensia juga terdapat gangguan kognisi lain seperti bahasa, orientasi, kemampuan membuat keputusan, berpikir abstrak, gangguan emosi dan perilaku. Gangguan-gangguan tersebut dapat mempengaruhi kepribadian seseorang yang mengalami demensia, kehidupannya tidak terlepas dari berbagai stressor, dengan adanya stressor akan menyebabkan masalah pada harga diri. 
Gejala demensia yang sering dialami lansia sepertilupa meletakkan barang, tersesat keluar rumah tanpa ditemani, emosi naik turun (Aspiani, 2014). Pikun menjadi sebutan orang tua yang sering mengalami hal-hal tersebut. Kemudian, lansia menjaga jarak dengan lingkungan dan lebih sensitif kondisi ini dianggap lumrah jika terjadi pada lansia atau umum disebut penyakit tua. Banyak orang menyepelekan penyakit ini memori seperti itu sebagai kondisi demensia membuat penyakit ini terabaikan (Janiwarti, Saragih, \& Pieter, 2011).

Perubahan tingkah laku pada demensia dapat memunculkan sikap empati yang sangat dibutuhkan anggota keluarga, yakni harus dengan sabar merawat klien. Perubahan perilaku lain lansia pada penderita demensia adalah delusi, halusinasi, depresi, kerusakan fungsi tubuh, cemas, disorientasi spasial, ketidakmampuan melakukan tindakan yang berarti, tidak dapat melakukan aktivitas sehari-hari secara mandiri, melawan, marah, agitasi, apatis, dan kabur dari tempat tinggal sehingga kebanyakan lansia merasa diri tidak berguna.

Data dari World Health Organization dan Alzaimer's Disease International Organization melaporkan jumlah total orang dengan demensia diseluruh dunia pada tahun 2016 diperkirakan mencapai 47,5 juta dan sebanyak 22 juta jiwa diantaranya berada dia Asia. Di Negara maju seperti Amerika Serikat saat ini ditemukan lebih dari 4 juta orang usia lanjut menderita penyakit demensia. Angka ini diperkirakan akan meningkat hampir 4 kali pada tahun 2050. Di antara mereka, $58 \%$ hidup dinegara-negara berpenghasilan rendah atau menengah, dan proporsi ini di proyeksikan meningkat menjadi $75 \%$ pada tahun 2050. Jumlah total kasus demensia baru setiap tahun di seluruh dunia hampir 7,7 juta, artinya bahwa setiap 4 detik terdapat 1 kasus demensia diperkirakan akan meningkat menjadi 75,6 juta pada tahun 2030 dan 135,5 juta pada tahun 2050.

Di Indonesia proporsi penduduk lansia terus meningkat. Indonesia termasuk lima besar negara dengan jumlah penduduk lansia terbanyak di dunia yakni mencapai 18,1 juta jiwa pada tahun 2010 atau $9,6 \%$ dari jumlah penduduk. penduduk lansia ini diproyeksikan menjadi 28,8 juta $(11,34 \%)$ dari total penduduk Indonesia pada tahun 2020, atau menurut proyeksi Bappenas jumlah penduduk lansia 60 tahun akan menjadi dua kali lipat (36 juta) pada tahun 2025. Sementara itu, umur harapan hidup penduduk Indonesia laki-laki dan perempuan) semakin meningkat dari 70,1 tahun 2010-2015 menjadi 72,2 tahun pada periode 20202035 (Badan Pusat Statistik Indonesia 2013).

Populasi lansia semakin meningkat setiap tahunnya dan sebagai akibat peningkatan tersebut dapat mempengaruhi kebutuhan lansia akan tempat tinggalnya. Kehadiran panti werdha kini sering dipilih sebagai alternative tempat tinggal pada lansia, pilihan tersebut dilakukan terutama oleh keluarga karena aktivitas yang padat berdampak pada kurangnya perhatian keluarga akan kebutuhan lansia. Pada lansia yang tinggal di panti akan memberikan stres tersendiri yang akan mempengaruhi ideal diri, citra diri, peran diri, gambaran diri yang negatif, yang akan mempengaruhi penurunan harga diri lansia.

Berdasarkan wawancara dengan petugas Panti Jompo yayasan Guna Budi Bakti didapatkan bahwa jumlah lansia sebanyak 72 orang pada bulan Februari, rata-rata lansia mengalami masalah dengan ingatan (demensia). Sebagian besar lansia menunjukkan perubahan perilaku misalnya mudah marah, mudah menangis, lupa dengan sesuatu, cenderung menghindar dari lingkungan sosial, menolak untuk bergabung dengan kelompok lansia lain pada saat melakukan kegiatan, lansia tidak mampu menyesuaikan diri dan hipersensitif terhadap kritikan orang. Bahkan ada lansia mengeluh merasa diri tidak berguna. Untuk itu, perlu suatu upaya untuk dapat mengidentifikasi harga diri lansia yang mengalami demensia.

\section{METODE PENELITIAN}

Jenis Penelitian survei analitik dengan menggunakan desain cross sectional untuk menganalisis hubungan Demensia Dengan Self Esteem Lansia dengan populasi seluruh lansia berjumlah 72 responden dengan menggunakan teknik total sampling. Waktu penelitian dilakukan pada bulan Februari sampai Agustus 2019.

Penelitian ini dilaksanakan Panti Jompo Yayasan Guna Budi Bakti Kelurahan Martubung Kec. Medan Labuhan Sumatra UtaraTahun 2019. Teknik pengambilan data dengan wawancara menggunakan kuesioner. Instrumen demensia berdasarkan pemeriksaan Mini Mental State Examination (MMSE) yang sudah baku (Anthony, LeResche, Niaz, Von Korff, \& Folstein, 1982). Skor penilaian demensia 0-30 dengan kategori demensia ringan : 21-30, demensia sedang : 11-20

Ganda Sigalingging ${ }^{1 *}$, Zulkarnain Nasution ${ }^{2}$, Rustina Pasaribu ${ }^{3}$

Fakultas Ilmu Keperawatan Universitas Darma Agung Medan, *Email: gandabonagabe@gmail.com 
dan demensia berat : $\leq 10$. Untuk menilai harga diri menggunakan instrumen sebanyak 30 item pertanyaan dengan kategori yaitu tinggi skor 1630 dan rendah skor 0-15. Instrumen telah dilakukan uji validitas dan reliabilitas diperoleh skor tertinggi 0,890 dan terendah 0,590 . Pengolahan data dengan menggunakan komputerisasi. Data dianalisis uji chi-Square pada taraf kepercayaan $95 \%$.

\section{HASIL}

Tabel 1. Distribusi Karakteristik Responden $\mathrm{N}=72$

\begin{tabular}{|c|c|c|}
\hline Variabel & Frekuensi (f) & Persentasi (\%) \\
\hline \multicolumn{3}{|l|}{ Umur } \\
\hline 50-65 tahun & 19 & 26,4 \\
\hline 66-81 tahun & 36 & 50,0 \\
\hline 82-97 tahun & 17 & 23,6 \\
\hline \multicolumn{3}{|l|}{ Jenis kelamin } \\
\hline Laki-laki & 32 & 44,4 \\
\hline Perempuan & 40 & 55,6 \\
\hline \multicolumn{3}{|l|}{ Pendidikan } \\
\hline Tidak Sekolah & 10 & 13,9 \\
\hline SD & 40 & 55,6 \\
\hline SMP/SLTP & 18 & 25,0 \\
\hline SMA/SLTA & 4 & 5,6 \\
\hline \multicolumn{3}{|l|}{ Pekerjaan } \\
\hline Tidak Bekerja & 20 & 27,8 \\
\hline Buruh & 26 & 36,1 \\
\hline Wiraswasta & 17 & 23,6 \\
\hline Petani & 9 & 12,5 \\
\hline \multicolumn{3}{|c|}{ Status Pernikahan } \\
\hline Menikah & 14 & 19,4 \\
\hline TidakMenikah & 58 & 80,6 \\
\hline \multicolumn{3}{|c|}{ Kriteria Demensia } \\
\hline Ringan & 24 & 33,3 \\
\hline Sedang & 32 & 44,4 \\
\hline Berat & 16 & 22,2 \\
\hline \multicolumn{3}{|c|}{ Tingkat Harga diri (Self } \\
\hline Rendah & 50 & 69,4 \\
\hline Tinggi & 22 & 30,6 \\
\hline
\end{tabular}

Berdasarkan hasil penelitian menunjukkan bahwa umur responden mayoritas umur 66-81 tahun sebanyak 36 $(50,0 \%)$, Jenis kelamin mayoritas perempuan $40(55,6 \%)$, pendidikan responden mayoritas SD $40(55,6 \%)$, dan pekerjaan responden mayoritas Buruh $26(36,1 \%)$, mayoritas mengalami demensia sedang sebanyak 32 $(44,4 \%)$, dan mayoritas mengalami harga diri rendah sebanyak $50(69,4)$.

Ganda Sigalingging ${ }^{1 *}$, Zulkarnain Nasution ${ }^{2}$, Rustina Pasaribu ${ }^{3}$

Fakultas Ilmu Keperawatan Universitas Darma Agung Medan, *Email: gandabonagabe@gmail.com 
Tabel 2. Hubungan Demensia dengan Harga Diri (Self Esteem) $\quad \mathrm{N}=72$

\begin{tabular}{|c|c|c|c|c|c|c|c|}
\hline \multirow[t]{3}{*}{ Demensia } & \multicolumn{4}{|c|}{ Harga Diri Lansia } & & & \\
\hline & \multicolumn{2}{|c|}{$\begin{array}{l}\text { Harga Diri } \\
\text { Rendah }\end{array}$} & \multicolumn{2}{|c|}{$\begin{array}{l}\text { Harga Diri } \\
\text { Tinggi }\end{array}$} & \multicolumn{2}{|c|}{ Total } & $p$-value \\
\hline & $\mathrm{n}$ & $\%$ & $\mathrm{n}$ & $\%$ & $\mathbf{N}$ & $\%$ & \\
\hline Demensia Ringan & 10 & 13,9 & 14 & 19,4 & 24 & 33,3 & 0.003 \\
\hline Demensia Sedang & 27 & 37,5 & 5 & 6,9 & 32 & 44,4 & \\
\hline Demensia Berat & 13 & 18,1 & 3 & 4,1 & 16 & 22,2 & \\
\hline Total & 50 & 69,4 & 22 & 30,6 & 72 & 100 & \\
\hline
\end{tabular}

Hubungan demensia dengan harga diri lansia, dari 32 orang lansia yang demensia sedang 27 $(37,5 \%)$ menujukkan harga diri rendah. Dari 24 Lansia yang demensia ringan, $10 \quad(13,9 \%)$ mengalami harga diri rendah, Dari $16(22,2 \%)$ lansia yang demensia berat $13 \quad(18,1 \%)$ menujukkan harga diri rendah. Hasil uji statistik menunjukan ada hubungan demensia dengan harga diri lansia dengan p.value $=0.003(p<0,05)$ yang berarti semakin tinggi tingkat demensia yang terjadi pada lansia, maka harga diri lansia semakin rendah.

\section{PEMBAHASAN}

\section{Demensia Pada Lansia}

Berdasarkan hasil penelitian menunjukan bahwa mayoritas lansia mengalami demensia sedang 32 orang $(44,4 \%)$ hal ini sesuai dengan penelitian sebelumnya yang menunjukan $45,4 \%$ lansia mengalami demensia sedang (Bidjuni, \& Masi, 2018). Demensia adalah suatu gangguan intelektual/daya ingat yang umumnya progresif dan irreversibel. Demensia merupakan kemunduran kognitif yang sedemikian beratnya, sehingga mengganggu aktivitas sosial dan pekerjaannya. Pada demensia juga terdapat gangguan kognisi lain seperti bahasa, orientasi, kemampuan membuat keputusan, berpikir abstrak, gangguan emosi dan perilaku. Gangguan-gangguan tersebut dapat mempengaruhi kepribadian seseorang yang mengalami demensia, kehidupannya tidak terlepas dari berbagai stressor, dengan adanya stressor akan menyebabkan masalah pada harga diri. Gejala demensia yang sering dialami lansia seperti lupa meletakkan barang, tersesat keluar rumah tanpa ditemani, emosi naik turun. Pikun menjadi sebutan orang tua yang sering mengalami hal-hal tersebut. Kemudian, lansia menjaga jarak dengan lingkungan dan lebih sensitif kondisi ini dianggap lumrah jika terjadi pada lansia atau umum disebut penyakit tua. Biasanya demensia sering terjadi pada orang berusia $>65$ tahun. Berdasarkan umur lansia yang menderita demensia mayoritas 66-81 tahun $(50.0 \%)$ dan terdapat $(23,6 \%)$ lansia yang berumur diatas 82 tahun yang termasuk golongan lansia yang membutuhkan perhatian penuh. Berdasarkan teori dinyatakan bahwa demensia merupakan penyakit degenerative yang sering terjadi pada orang-orang lanjut usia (Aristawati, Ratnawati, \& Imavike, 2016).

Dimana lansia sering lupa dengan apa yang baru terjadi atau baru dilakukannya, kesulitan dalam melakukan perintah dan melakukan kegiatan sehari- hari, gangguan penilaian, kebingungan dan perubahan kepribadian. Lansia adalah kelompok penduduk berumur tua, golongan penduduk yang mendapat perhatian atau pengelompokan tersendiri ini adalah populasi berumur 60 tahun atau lebih. Demensia merupakan salah satu masalah kesehatan yang paling umum terjadi pada kelompok lansia, karena kemunduran fungsi- fungsi tubuh akan 
mempengaruhi keadaan lansia dan dapat mengganggu aktivitas hidup sehari-hari, aktivitas sosial maupun pekerjaan lansia. Pada demensia juga terdapat gangguan kognisi lain seperti bahasa, orientasi (waktu, tempat, person), kemampuan membuat keputusan, berpikir abstrak, gangguan emosi dan perilaku (Bustan, 2015).

Biasanya demensia timbul secara perlahan dan menyerang usia di atas 60 tahun. Demensia bukan merupakan bagian proses penuaan yang normal. Sejalan dengan bertambahnya umur maka perubahan dalam otak menyebabkan hilangnya beberapa ingatan, terutama pada ingatan jangka pendek dan perubahan kemampuan belajar. Gejala demensia tahap lanjut biasanya akan muncul berupa depresi pada lansia, dimana sering kali lansia akan menjaga jarak dengan lingkungan dan lebih sensitif. Kondisi seperti ini akan menimbulkan penyakit lain dan biasanya akan memper berat masalah yang terjadi.

Berdasarkan data dari World Health Organization dan Alzaimer's Disease International Organization melaporkan jumlah total orang dengan demensia diseluruh dunia pada tahun 2016 mencapai 47,5 juta jiwa dan proporsi ini di proyeksikan meningkat menjadi $75 \%$ pada tahun 2050. Hal ini sejalan dengan data Kemenkes 2016 di Indonesia jumlah Orang Dengan Demensia (ODD) pada tahun 2013 mencapai satu juta orang, diperkirakan akan meningkat dua kali lipat pada tahun 2030, dan menjadi empat juta orang ditahun 2050.

Berdasarkan hasil penelitian diperoleh 22,2\% lansia mengalami demensia berat dan 18,1\% mengalami harga diri rendah. Berdasarkan kondisi lapangan saat peneliti melakukan observasi didapatkan bahwa ternyata lansia mayoritas lupa dengan hal-hal yang baru saja terjadi, seperti pertanyaan yang baru saja ditanyakan peneliti, lansia juga mengalami gangguan pada orientasi waktu, tanggal, musim dan lainya, mayoritas lansia tidak mampu menjawab dengan benar dan hanya terdiam tanpa memberi respon, lansia juga terlihat gelisah dan mudah marah. Hal ini sejalan dengan teori bahwa lansia yang mengalami demensia akan mengalami keadaan yang sama seperti orang depresi yaitu akan mengalami deficit aktivitas kehidupan sehari-hari (AKS) (Azizah, 2011; Kindell, Keady, Sage, \& Wilkinson, 2017).

Gejala yang sering menyertai demensia adalah: Gejala awal seperti kinerja mental menurun, fatique, mudah lupa, dan gagal dalam tugas. Gejala lanjut yaitu gangguan kognitif, gangguan afektif dan gangguan perilaku dan gejala umum yaitu mudah lupa, aktivitas sehari-hari terganggu, disorientasi, cepat marah, kurang konsentrasi, resiko tinggi jatuh. oleh sebab itu, perlu menciptakan upaya untuk meningkatkan kesehatan kognitif lansia dengan mengadakan berbagai kegiatan agar lansia aktif secara mental seperti, bermain kartu dan alat musik, mengadakan sosialisasi, membuat catatan lansia sebagai pengingat dan melakukan aktivitas fisik secara rutin (Idrus, 2007; Febrianti, 2019).

\section{Harga Diri Lansia}

Hasil penelitian menunjukan mayoritas lansia mengalami harga diri rendah $69,4 \%$. Harga diri rendah adalah suatu evaluasi diri yang negatif dan berhubungan dengan perasaan yang lemah, tak berdaya, ketakutan, tidak berharga, dan tidak memadai. Lansia akan mengalami banyak perubahan dan penurunan fungsi fisik dan psikososial, perubahan ini dapat menimbulkan berbagai masalah pada lansia yang akan berpengaruh dalam menilai dirinya sendiri. Harga diri menjadi hal yang sangat penting bagi lansia karena harga diri adalah rasa dihormati, diakui, diterima dan bernilai bagi lansia yang didapatkan dari orang lain (Potter, \& Perry, 2009). Harga diri rendah adalah suatu evaluasi diri yang negatif dan berhubungan dengan perasaan yang lemah, tak berdaya, ketakutan,tidak berharga, dan tidak memadai (Nugroho, 2008; World Health Organization, 2008). Harga diri rendah akan berkaitan dengan kejadian depresi pada lansia sehingga perlunya peran keluarga yang positif. Penelitian sebelumnya di kota Bandar Lampung didapatkan nilai $O R=215,543$ yang berarti peran keluarga tidak baik berisiko 215,543 kali akan menimbulkan gejala depresi pada para lansia (Pribadi, 2017).

Berdasarkan hasil penelitian di Amerika Serikat, ditemukan bahwa sebanyak $26 \%$ orang

Ganda Sigalingging ${ }^{\text {** }}$, Zulkarnain Nasution ${ }^{2}$, Rustina Pasaribu ${ }^{3}$

Fakultas Ilmu Keperawatan Universitas Darma Agung Medan, *Email: gandabonagabe@gmail.com 
yang berusia $60-80$ tahun keatas mengalami harga diri rendah, demikian juga hasil penelitian di Thailand menunjukkan bahwa 19,3\% lansia mengalami harga diri rendah. Lansia yang mengalami harga diri rendah memiliki perasaan malu, kurang percaya diri, minder, tidak berguna, tidak mampu, menyalahkan diri, menarik diri, dan keinginan yang tidak tercapai misalnya berkumpul dengan keluarga (Potter, \& Perry, 2009; Nanthamongkolchai, Nanthamongkolchai, Tuntichaivanit, Munsawaengsub, Munsawaengsub, Charupoonphol, \& Charupoonphol, 2009; Aristawati, Ratnawati, \& Imavike, 2016).

Pada umumnya gambaran lansia yang memiliki harga diri rendah cenderung akan mengalami depresi, menarik diri dari lingkungan sosial dan hipersensitif terhadap kritikan orang lain (Yusuf, 2016; Khan, 2012). Berdasarkan hasil penelitian didapatkan bahwa para lansia memiliki pengungkapan diri yang negatif dan mengalami masalah dengan interaksi sosial, hal ini dibuktikan dari hasil penelitian mayoritas lansia menarik diri, tidak puas dan bahagia dengan keadaan saat ini, lansia cenderung cemas mengenai hidupnya dan sering menangis (Aspiani, 2014).

Pada umumnya lansia jarang di kunjungi oleh keluarga maupun kerabatnya,hal ini disebabkan mayoritas lansia tidak menikah sebanyak 58 orang $(80,6 \%)$, sehingga lansia hanya memiliki keluarga terdekat karena tidak memiliki keturunan. Hal ini dapat mempengaruhi harga diri lansia karena lansia akan merasa bahwa dirinya tidak berguna dan berdaya.

Berdasarkan teori dibuktikan bahwa kegagalan individu dalam melanjutkan sekolah, pekerjaan, pernikahan akan mengakibatkan individu menghindari hubungan intim, menjahui orang lain, putus asa dalam karir dan akan memilih untuk hidup sendiri, hal ini dapat mengakibatkan individu tersebut akan mengalami harga diri rendah.

\section{Hubungan Demensia Dengan Harga Diri (Self Esteem)}

Hasil penelitian hubungan demensia dengan harga diri self esteem lansia diperoleh nilai $p=0,003$ yang menunjukan ada hubungan demensia dengan harga diri (Self esteem) lansia. Berbeda dengan penelitian yang telah dilakukan di Provinsi Sulawesi Utara menunjukan tidak ada hubungan antara tingkat demensia dengan konsep diri lansia di BPLU Senja Cerah Provinsi Sulawesi Utara dengan $p=0,972$ (Bidjuni, \& Masi, 2018).
Berdasarkan penelitian didapatkan mayoritas lansia yang demensia cenderung menarik diri, mudah putus asa, depresi, sulit menyesuaikan diri dan hipersensitif serta kehilangan peran diri, yang mana ada beberapa lansia yang kadang mudah marah dan mudah tersinggung, merasa dirinya sudah tidak berguna dan tidak berdaya, merasa dirinya lemah bahkan sudah tidak dapat berbuat apa-apa lagidan dari hasil observasi diagnosa dokter ditemukan 7 orang lansia mengalami skizofrenia dan ingin melukai diri sendiri bahkan orang lain, hal ini dikarenakan mayoritas lansia memiliki gangguan pikiran, perilaku, harapan hidup yang rendah, cenderung bunuh diri dan tidak mampu membangun, membina dan mempertahankan hubungan sosial akibat emosi yang abnormal. Hal ini sesuai dengan teori yang menunjukkan gejala demensia yang muncul biasanya berupa depresi pada lansia, dimana sering kali lansia menjaga jarak dengan lingkungan dan lebih sensitif. Kondisi seperti ini dapat saja diikuti oleh munculnya penyakit lain dan biasanya akan mempengaruhi kondisi lansia. Pada tahap lanjut, demensia menimbulkan perubahan tingkah laku yang semakin mengkhawatirkan, sehingga perlu sekali bagi masyarakat memahami dengan baik perubahan tingkah laku yang dialami lansia penderita demensia (Janiwarti, Saragih, \& Pieter, 2011; Widyastuti, 2011).

Pada umumnya demensia lebih banyak menyerang kaum wanita daripada kaum laki-laki, penderita demensia sering sekali akan menghindari aktivitas yang rumit, seperti membaca dan bekerja, mereka akan lebih memilih berdiam diri menghindar dari lingkungan sosial, penderita demensia yang gagal mengubah pola hidupnya dapat menyebabkan frustasi karena ketidakmampuan melakukan tugas sehari-hari (Mulia, 2018; Nurlaili, 2012). Sama halnya ketika dilakukan penelitian, ditemukan mayoritas lansia tidak mau bergabung dengan komunitas lansia lainnya dan menolak untuk mengikuti senam, dan saat peneliti memberi pilihan antara tinggal dirumah atau pergi keluar jalan- jalan dengan teman atau keluarga, mayoritas lansia lebih memilih untuk tinggal dirumah (Azizah, 2011; Dariuszky, 2004; Aspiani, 2014).

Berdasarkan teori menunjukan faktor setressor pencetusnya seperti pensiun yang terpaksa, kematian pasangan, kemunduran kemampuan atau kemampuan fisik, dukungan sosial, keuangan, penghasilan dan rumah tinggal sehingga 
mempengaruhi rasa aman lansia dan menyebabkan depresi. Hal ini sesuai dengan penelitian sebelumnya di Panti Jompo di kota Medan (Sigalingging, 2017).

Depresi pada lansia dapat disebabkan oleh berbagai faktor meliputi; Faktor psikologis, motivasi masuk panti werdah sangat penting bagi lanjut usia untuk menentukan tujuan hidup dan apa yang ingin dicapai dalam kehidupan di panti,tempat dan situasi yang baru, orang-orang yang belum dikenal, aturan dan nilai-nilai keterasingan merupakan setressor bagi lansia yang membutuhkan penyesuaian diri; Faktor psikososial, menurunnya kapasitas hubungan keakraban dengan keluarga dan berkurangya interagsi dengan keluarga yang dicintai dapat menimbulkan perasaan tidak berguna, merasa disingkirkan tidak dibutuhkan lagi dan kondisi ini dapat berperan ke depresi (Darmojo, \& Martono, 2004; Sigalingging, 2017). Adapun upaya yang dapat dilakukan untuk mengatasi permasalah yang terjadi pada lansia yang berkaitan dengan gangguan psikologis pada lansia yaitu dengan menciptakan lingkungan yang tenang, menggalakkan kegiatan hobi yang disesuaikan dengan kemampuan lansia. Melakukan terapi aktivitas kelompok (TAK) dengan senam dan bermain catur, dan terapi kognitif perilaku misalnya menyediakan alat musik dengan alunan lembut, melakukan permainan (scrabble, catur dan puzzle) untuk melatih organ otak dalam stimulus daya ingat. Memberikan ruang bercengkerama sesama lansia untuk boleh berbagi pengalaman di masa lalu.

\section{SIMPULAN}

Berdasarkan hasil penelitian dan pembahasan dapat diambil kesimpulan sebagai berikut:

Lansia yang mengalami demensia sebanyak 32 orang (44\%); yang menunjukkan harga diri rendah (self esteem) sebanyak 50 orang $(69,4 \%)$. Hasil uji statistik menunjukkan ada Hubungan Demensia dengan Harga Diri (Self Esteem) dengan nilai $p$ value 0,003

\section{SARAN}

Kepada Yayasan panti jompo Guna Budi Bakti Medan agar menciptakan lingkungan yang aman dan nyaman, dengan memfasilitasi kegiatan sesuai kebutuhan lansia yaitu melakukan terapi aktivitas kelompok (TAK) dengan senam dan bermain catur, dan terapi kognitif perilaku misalnya menyediakan alat musik dengan alunan lembut, melakukanpermainan (scrabble, caturdan puzzle) untuk melatih organ otak dalam stimulus daya ingat dan tercipta perasaan yang riang gembira sehingga kualitas hidup lansia tetap sehat, mandiri, berguna, dan produktif.

Untuk meningkatkan harga diri lansia sebaiknya menyapa lansia dengan dengan sopansantun serta menerapkan komunikasi yang terapetik seperti memanggil nama akrap "Acong dan Ama, berbicara dengan tenang sambil memberikan senyuman, menyentuh tangan dan pundak, menunjukkan rasa hormat dalam bersikap dan bertindak misalnya saat melakukan sesuatu gunakan kalimat menghargai jangan memerintah.

\section{DAFTAR PUSTAKA}

Anthony, J. C., LeResche, L., Niaz, U., Von Korff, M. R., \& Folstein, M. F. (1982). Limits of the 'Mini-Mental State'as a screening test for dementia and delirium among hospital patients. Psychological medicine, 12(2), 397408.

Aristawati, E., Ratnawati, R., \& Imavike, F. (2016). Studi Fenomenologi: Pengalaman Kesepian pada Lansia yang Tinggal Dirumah Seorang Diri di Desa Tunggul Wulung-Pandaan. The Indonesian Journal of Health Science, 6(1).

Aspiani, R. Y. (2014). Buku Ajar Asuhan Keperawatan Gerontik: Aolikasi NANDA, NIC dan NOC.

Azizah, L. M. R. (2011). Keperawatan lanjut usia. Yogyakarta: Graha IImu, 45.

Badan Pusat Statistik Indonesia. (2013). Indonesia population projection 2010-2035. Statistics Indonesia.

Bidjuni, H., \& Masi, G. (2018). Hubungan tingkat demensia dengan konsep diri pada lanjut usia di bplu senja cerah provinsi sulawesi utara. Jurnal keperawatan, 6(1).

Bustan, M. N. (2015). Manajemen Pengendalian Penyakit Tidak Menular. 
Dariuszky, G. (2004). Membangun harga diri. Bandung: CV. Pionir Jaya.

Darmojo, R. B., \& Martono, H. (2004). Geriatri (IImu Kesehatan Usia Lanjut). Edisi ke3. Jakarta: Balai Penerbit FKUI, 3-4.

Febrianti, S. (2019). Asuhan keperawatan gangguan pemenuhan kebutuhan personal hygiene pada klien demensia di UPTD PSLU Tresna Werdha Natar Kabupaten Lampung Selatan Tahun 2019 (Doctoral dissertation, Poltekkes Tanjungkarang).

Idrus, M. F. (2007). Depresi pada Penyakit Parkinson. Cermin Dunia Kedokteran, 34, 3.

Janiwarti, B., Saragih, M., \& Pieter, H. Z. (2011). Pengantar Psikopatologi Untuk Keperawatan. Jakarta: Kencana.

Khan, R. I. (2012). Perilaku Asertif, Harga Diri dan Kecenderungan Depresi. Persona: Jurnal Psikologi Indonesia, 1(2).

Kindell, J., Keady, J., Sage, K., \& Wilkinson, R. (2017). Everyday conversation in dementia: A review of the literature to inform research and practice. International journal of language \& communication disorders, 52(4), 392-406.

Mulia, T. Y. P. B. (2018). Permainan Dakon Sebagai Terapi Pikun (Demensia) Pada Lanjut Usia. IJMS-Indonesian Journal on Medical Science, 5(2).

Nanthamongkolchai, S., Nanthamongkolchai, S., Tuntichaivanit, C., Munsawaengsub, C., Munsawaengsub, C., Charupoonphol, P., \& Charupoonphol, P. (2009). Factors influencing life happiness among elderly female in Rayong Province, Thailand.
Nugroho, W. (2008). Keperawatan Gerontik \& Geriatrik, edisi 3. Jakarta: EGC.

Nurlaili, N. (2012). Menopause dan Pengaruhnya Dalam Kehidupan Perkawinan. Marwah: Jurnal Perempuan, Agama dan Jender, 11(2), 1-20.

Potter, P. A., \& Perry, A. G. (2009). Buku ajar fundamental keperawatan (Monica Ester, Devi Yulianti \& Intan Parulian, Penerjemah). Jakarta: EGC.

Pribadi, T. (2017). Hubungan peran keluarga dengan depresi pada lansia di kecamatan Way Halim Bandar Lampung tahun 2015. Holistik Jurnal Kesehatan, 11(2), 82-89.

Sigalingging, G. (2017). Determinan depresi pada lanjut usia di Panti Jompo Harapan Jaya Marelan Medan. An-Nadaa: Jurnal Kesehatan Masyarakat, 4(1), 6-10.

Widyastuti, R. H. (2011). Gambaran beban keluarga dalam merawat lansia dengan demensia di kelurahan Pancoranmas, Depok, Jawa Barat: Studi Fenomenologi. Jurnal Kesehatan (The Journal of health) volume 1 no 7 Juni 2011 hal 53-57, 1(7), 53-57.

World Health Organization. (2008). WHO report on the global tobacco epidemic,8: the MPOWER package. Diakses dari: https://www.who.int/tobacco/mpower/mpower $r$ eport full 2008.pdf

Yusuf, N. P. (2016). Hubungan harga diri dan kesepian dengan depresi pada remaja. In Seminar ASEAN 2nd Psychology \& Humanity, Psychology Forum UMM (pp. 19-20). 